Archived version from NCDOCKS Institutional Repository http://libres.uncg.edu/ir/asu/

\title{
Appalachïan
}

$\overline{B \text { O O N E, N O R T H C A R O L I N A }}$

\section{Anti-Consumption In East Germany: Consumer Resistance To Hyperconsumption}

\author{
By: Pia A. Albinsson, Marco Wolf, and Dennis A. Kopf
}

\begin{abstract}
A common ideology of consumption is that more things translate to a higher quality of life. This paper challenges this ideology. We explore the consumption resistance (anti-consumption) of "cheap and low-quality" goods experienced by consumers living in former East Germany. We interviewed men and women who lived in East Germany about their consumption experiences before, during, and after Reunification. We present three emergent themes: "consumer resistance - emergence of anti-consumption," "continued frugality - resistance to contemporary throwawayism?," and "Western Brand Resistance." Our research reveals a deep aversion among East Germans to the modern, bureaucratic and obligatory practice of throwawayism and hyperconsumption. We find feelings of resentment and betrayal and discover a much deeper issue with consumption: the fact that consumption is often a disillusioning experience and that material possessions and abundance are actually driving East Germans apart - making them feel less socially connected. As East Germans are swept up in the global economic juggernaut of capitalism, they find that their collective identity and sense of community is also swallowed up. Upon this realization, dialogism appears, and we uncover this as resistance to Western practices of hyperconsumption, frugality-as-an-ethic and an aversion to low quality throwaway-type products. Based on our findings, we make suggestions for marketing practice and for future research.
\end{abstract}

Albinsson, P. A., Wolf, M. and Kopf, D. A. (2010), Anti-consumption in East Germany: consumer resistance to hyperconsumption. Journal of Consumer Behaviour, 9: 41 2-425. doi:10.1002/cb.333. Publisher version of record available at: https://onlinelibrary.wiley.com/doi/10.1002/cb.333 


\title{
Anti-consumption in East Germany: Consumer resistance to hyperconsumption
}

\author{
Pia A. Albinsson ${ }^{1 *}$, Marco Wolf $^{2}$ and Dennis A. Kopf ${ }^{3}$ \\ ${ }^{1}$ Walker College of Business, Department of Marketing, Appalachian State University, \\ Raley Hall 4113, Boone, NC 28608, USA \\ ${ }^{2}$ Department of Marketing, University of Soutbern Mississippi, 730 East Beach Blvd, \\ Long Beach, MS 39560, USA \\ ${ }^{3}$ Department of Marketing, University of Wisconsin, Whitewater, 800 West Main Street, \\ Whitewater, WI 53190-1790, USA
}

- A common ideology of consumption is that more things translate to a higher quality of life. This paper challenges this ideology. We explore the consumption resistance (anticonsumption) of "cheap and low-quality" goods experienced by consumers living in former East Germany. We interviewed men and women who lived in East Germany about their consumption experiences before, during, and after Reunification. We present three emergent themes: "consumer resistance - emergence of anti-consumption," "continued frugality - resistance to contemporary throwawayism?," and "Western Brand Resistance."

Our research reveals a deep aversion among East Germans to the modern, bureaucratic and obligatory practice of throwawayism and hyperconsumption. We find feelings of resentment and betrayal and discover a much deeper issue with consumption: the fact that consumption is often a disillusioning experience and that material possessions and abundance are actually driving East Germans apart - making them feel less socially connected. As East Germans are swept up in the global economic juggernaut of capitalism, they find that their collective identity and sense of community is also swallowed up. Upon this realization, dialogism appears, and we uncover this as resistance to Western practices of hyperconsumption, frugality-as-an-ethic and an aversion to low quality throwaway-type products. Based on our findings, we make suggestions for marketing practice and for future research.

\footnotetext{
*Correspondence to: Pia A. Albinsson, Walker College of Business, Department of Marketing, Appalachian State University, Raley Hall 4113, Boone, NC 28608, USA.

E-mail: albinssonpa@appstate.edu
}

\section{Introduction}

... and our belief...that the West was the center of the world was pushed aside by reality. You didn't just get what was great, but also the negative sides of capitalism. (Birgit) 
The products are not that great anymore. I notice that especially when things are on sale, the cheap stuff is not worth it. If you buy cheap you buy twice... Even though we now live in a throwaway society, I live by the motto you may need it in the future'. I store a lot of items in my basement just in case. (Detlef)

This paper examines the attitudes former East Germans hold against Western consumer culture and the disillusionment they felt after realizing that their participation did not necessarily make their lives better. East Germans now question the logic of Western consumption models by not only voicing concerns but also re-practicing former East German consumption practices in an attempt to limit the social consequences of creating excessive waste. In short, they realized that buying more did not necessarily make them happier.

\section{Historical background}

East Germans were introduced to a specific set of socio-political factors under communist rule that shaped their mentality for over 40 years. Encouraged by official ideology, the creation of the so-called socialist personality, was a major aim of the SED (East Germany's Communist party). This was to advocate the Marxist idea of the collective life by giving up individual concerns in favor of the betterment of society. Many East Germans, especially those generations that grew up after WWII, developed an emotional bond with the GDR (German Democratic Republic), which considered itself distinct from its Western counterpart; socialist and part of the Eastern Bloc. Rather than focusing on individual goals, communism expected individuals to work for the common good (Madarász, 2006; Spehrlich, 2006).

The political leadership exerted great effort to involve the population, thereby overcoming the state-society divide to some extent. The slogan 'Vom ich zum wir' (from me to us) succinctly expressed central political intentions, which offered the population the feeling of being part of the socialist project in turn for its endorsements; peace, humanity, security, safety, and education (Meuschel, 1992; Madarász, 2006). In response to propaganda and the circumstances of life in the GDR, values became slowly ingrained, resulting in attitudes and behaviors that established social norms. Individual choice, self-fulfillment, and expression through possessions became subordinate goals for many East Germans (Ludwig, 1999; Veenis, 1999).

Although materialist ideology was not able to fulfill its promises in East Germany, the quest for material goods turned out to be one of the most important guidelines and themes in the everyday life of most East Germans. This was partly due to central regulation and continuous scarcity of consumer goods, which forced people to spend an enormous amount of time and energy on the acquisition of basic material goods (Veenis, 1999).

Thus, the GDR's quick shift from a planned economy to a demand economy provides a rare opportunity to explore how cultural ideology affects consumption patterns. East Germans witnessed the loss of familiar products, the introduction of new brands and a flood of advertising and retail outlets in a short time frame. This context, characterized by abrupt change, has been important for consumer research. Previous studies in this context have focused on purchasing and consumption behavior (Feick et al., 1995; Rojsek, 2001), complaints and consumer voice behavior (Gurdon et al., 1999), opinion leadership among women (Coulter et al., 2000), and brand commitments (Coulter et al., 2003). While there is a surge in consumerism in many developing and former communist societies in Asia (Etzioni, 1998), we find that East Germans are resisting hyperconsumption and throwawayism.

\section{Consumption, materialism, and waste}

Economic growth is the yardstick upon which societies measure themselves. In industrialized societies, these ideals have elevated consumption to the level of a virtue (Kopf et al., 
in press). In order to spur consumption, corporations have been accused of designing products to be perceived as obsolete within a few months and are designed to only last for a predetermined time period. Consumers follow and exchange old for new without much thought of the consequences. Some researchers have even labeled these consumption patterns as "promiscuous" where consumers have informal, opportunistic and short-lived relationships with products and brands to seek variety (Denegri-Knott and Molesworth, 2009). Western societies consider consumption of products to be a road to happiness (Hetrick, 1989), but more recent research indicates that many consumers now believe that over-consumption can create feelings of stress, fatigue, unhappiness, or disillusionment (Zavestoski 2002b). Kilbourn et al. (1997) concludes that over-consumption and materialism are contributing to a long-run decline of quality of life in industrial societies; which in turn may cause a form of anti-materialism as a consumer response (Santino, 1996).

To understand East Germans' practices of resisting Western hyperconsumption, it is helpful to examine their opposition as a type of anti-consumption. Anti-consumption entails an active and passive form of resistance by the consumer. In essence, research on anticonsumption focuses on why individuals fail to consume or why they actively choose not to consume (Close and Zinkhan, 2009). Anticonsumption attitudes may simply be a function of preference of choosing to consume one product over another whereas more profound types of anti-consumption involve actual resistance to, distaste of, or even rejection of consumption in general (Zavestoski, 2002a). Specific anti-consumption behavior, grounded in societal and ethical concerns, has also been labeled by researchers as ethical consumption (Shaw and Newholm, 2002) and broadly encompasses concerns for the environment (i.e., environmental degradation, destruction of rainforests, or threatened species) as well as concerns for others (i.e., fair trade and labor exploitation) (Freestone and McGoldrick, 2008).
Anti-consumption can also include a wide variance in ideals and motivations. For example, ideal versus radical green consumerism (Moisander and Pesonen, 2002) has been studied as well as more benign personal concerns such as life simplification (i.e., CraigLees and Hill, 2002; Etzioni, 1998; Hueneke, 2005). The target of anti-consumption behavior also differs between those who want to generally reduce their overall consumption and those who direct their effort toward specific brands and products (Craig-Lees and Hill, 2002; Iyer and Muncy, 2009; Sandikci and Ekici, 2009). Common to each form of anticonsumption, is the aim to resist the forces of mass marketing and mass-produced meanings (Peneloza and Price, 1993). Consumer resistance research can be considered a subset of the broader concept of anti-consumption (Galvagno, 2010). For a more detailed discussion on the conceptual relationship of consumer resistance, anti-consumption, and “non-consumption" see Cherrier et al. (2010).

Lately, resistance research has focused on ways consumers try to limit wasteful consumption and resist buying from traditional retail outlets. For example, consumers prolong the life of clothes and obtain second-hand goods at clothing exchanges (Albinsson and Perera, 2009), dispose of used or unwanted goods through alternative disposal modes such as flea markets (and obtain new "lightly used" goods) (Sherry, 1990), auctions and e-auctions (Cheetham, 2009; Denegri-Knott and Molesworth, 2009), by voluntary downshifting and simplifying their lifestyles (Ballantine and Creery, 2010; Cherrier and Murray, 2007; Cherrier, 2009a, b; Shaw and Moraes, 2009; Schor, 1998), by refraining or limiting their overall consumption (Lastovicka et al., 1999) or even aiming not to consume (i.e., nonconsumption) (Shaw and Moraes, 2009). The current study adds to this literature by showing how East Germans seek to efficiently use resources such as consumer durables and oftentimes store or repair old or broken products for possible future use.

This discussion of extant literature unveils a growing understanding of anti-consumption in 
its many forms and motivations. However, we respond to recent calls for more studies of anti-consumption in additional contexts and cultures (Sandikci and Ekici, 2009) as well as more factors (i.e., differing cultures and differing market structures) likely to influence anti-consumption behavior (Iyer and Muncy, 2009). This study builds on the work of Zavestoski (2002b) and contributes to our understanding of consumer resistance by examining the extent to which alternative consumption practices have evolved through the experienced meanings of living through a sudden market transition. We draw from phenomenological interviews with East German consumers to understand how and why an ethic of anti-consumption has become so prevalent in East German culture, but also to find the main philosophical underpinnings of anti-consumption. Through our analysis, we are able to break down the distinction of anticonsumption driven by personal motivations versus anti-consumption driven by societal or ideological factors (Lee et al., 2009a; Sandikci and Ekici, 2009). Our findings support a dialogical perspective of anti-consumption, where the interplay of personal, societal, and ideological motivations has created a rich anti-consumption culture in East Germany.

\section{Metbod}

This study utilizes an interpretive methodological approach (Lincoln and Guba, 1985) allowing us to understand anti-consumption and resistance of brands and products from a consumer perspective. We conducted 12 informal, 20 formal, and additional follow-up interviews with consumers from the former GDR during a 5-year period to gain insight into whether the restrictions in their consumption during the years of living in a planned economy affected their current behavior.

All interviews were conducted in German, digitally recorded and transcribed verbatim in German immediately after each interview. One of the authors, who is bilingual in German and English, later translated the interviews into
English, producing over 300 pages of interview data. All interviews were conducted in the participants' homes, except for one, which was held in a coffee shop, because the selfemployment situation did not allow for a home visit. Two of our interviewees re-located into the western region of Germany in the mid 1990s but were included in the study as they visited their hometowns on a frequent basis. Participants ranged in ages from 27 to 78 and interviews lasted from 60 to 120 minutes (see Table 1 for participant profiles).

To recruit potential participants, purposive sampling was used which allowed participants to be selected on the basis of specific criteria (i.e., those who have lived most of their life in the former GDR). This selection method also permitted the inclusion of diversity (e.g., age, education, and professional background) in the sample (Lincoln and Guba, 1985). No incentive was offered for participation. Most participants resided in small to medium size towns in close proximity to Berlin. Interview guidelines covered a wide range of topics including educational and cultural background, consumption experience in a planned economy, accumulation of possessions, replacement cycles, relationships between consumers,

Table 1. Participant profiles

\begin{tabular}{llll}
\hline Pseudonym & Gender & Age & Profession \\
& & & \\
Heinz & Male & 69 & Retired \\
Andy & Male & 31 & Manufacturing \\
Wolfgang & Male & 52 & Self Employed \\
Jan & Male & 45 & Store Manager \\
Iris & Female & 44 & Store Clerk \\
Birgit & Female & 53 & Health Care \\
Rainer & Male & 55 & Physician \\
Armin & Male & 78 & Retired Teacher \\
Detlef & Male & 53 & Self Employed \\
Helmut & Male & 66 & Retired \\
Michael & Male & 46 & School Teacher \\
Norbert & Male & 51 & School Principal \\
Sören & Male & 27 & Military \\
Sieghard & Male & 62 & Retired \\
Peter & Male & 55 & Forest Service \\
Bertram & Male & 46 & Repair service \\
Theo & Male & 59 & Retired \\
Margot & Female & 48 & Social Work \\
Mandy & Female & 31 & Administrative \\
Ulla & Female & 45 & Customer Service \\
& & & \\
\hline
\end{tabular}


participation in East Germany's underground economy, and topics informing us about consumption during the transition and postunification period.

The phenomenological focus of the interviews allowed participants to provide thick descriptions about their experience as consumers in the former GDR, their consumption during the transition of re-unification, and their consumption 15-20 years after re-unification. Contrary to some previous research, our informants were not self-identified as anticonsumers/non-consumers, voluntary simplifiers or ethical consumers (Cherrier, 2009a,b; Shaw and Newholm, 2002; Zavestoski, 2002b). Instead, the anti-consumption themes, categories, and relationships emerged from the data during the interview process as a response to participants' lived experiences during the market transition. We continued conducting interviews until our themes were saturated and no additional refinements emerged from the addition of more participants (Glaser and Strauss, 1967). Analysis and review of the data were done independently by the three researchers through iterative readings in search for emergent and recurring themes. After independent coding of the data, the authors discussed the meaning of the themes and analyzed the data (for similar approaches see Kozinets and Handelman, 2004; Thompson and Arsel, 2004).

\section{Findings}

While most participants recognize the positive changes associated with becoming a market economy, our informants continue their struggle to accept the individualistic ideal and the new philosophies of hyperconsumption and throwawayism. They were brought up in the socialist paradigm that promised a rising standard of living through collective responsibility. Economic necessity required them to save, to repair and not to dispose of items that could be used in the future (Ludwig, 1999). With the transition to a demand economy, this necessity vanished, but many consumers still choose to integrate their cultural values and refuse to participate in wasteful consumption.

This research identifies three main themes that explain East German resistance to fully adopt models of Western consumption. The themes are discussed in the following order: "consumer resistance - emergence of anticonsumption," "continued frugality - resistance to contemporary throwawayism?," and "Western Brand Resistance." These three themes help us understand how the former collective view may still be adhered to and affect consumption decisions years after transitioning to a market economy.

\section{Consumer resistance - emergence of anti-consumption}

With the fall of the Wall in October 1989 many East Germans traveled to the West to satisfy their curiosity about Western consumer culture. To make sense of anti-consumption patterns of East Germans, we asked our informants to share their first experiences with Western consumption. Our interviewees described their first experience as "colorful" with an abundance of goods. Some were so overwhelmed that they ended up not purchasing anything. Michael recalled his childhood memories of shortages and lack of choices, and remembers being delighted by the new opportunities for consuming anything at anytime. The majority of our informants expressed similar first impressions regarding Western consumption. However, some informants also shared that their enthusiasm for Western consumer culture changed as political efforts to unify the countries progressed. This is consistent with recent findings about the roots of consumer resistance, that it can be viewed as a defensive reaction against what is perceived as ideologically adverse (Cherrier et al., 2010). Our informants voiced feelings of aversion against the oversupply of consumer goods struggling to find a fit between past values of refraining from unnecessary consumption and current pressure to partake in hyperconsumption. 
You pretty much tried to fit into the consumer society. It is not so much the case that you try to maintain your hard acquired goods for a very long time anymore. You can just go and buy new things. It is strange, bow one opened up to that kind of thinking after a while. We used to bave things repaired if they break, but you can't find anyone who does repairs anymore. Now you are only left with trashing it and buying new - I don't like it. (Birgit)

As Birgit is attempting to maintain her behavior of having broken goods repaired, she realizes that she has no other choice than to "throw away and consume more." Birgit told us that she does not see the point of disposing of a perfectly fine product due to a missing or broken part. She reluctantly accepts the new reality of hyperconsumption, but states that she also "became more conscious of what she buys."

The reluctance and resistance of excessive consumption can also be attributed to the loss of joy of acquiring consumer goods. Goods were suddenly available, yet, the experience of acquiring goods suffered. Rainer, a 55-year-old physician expressed that "today's shopping is not fun anymore. One can have everything for money... but back then it was more like a competition...today, it is not special anymore." Iris, a 44-year-old store clerk, shared a similar sentiment:

You were really running from the Kinderkaufhaus (children's store) to the Jugendmode (young fasbion) and from the Jugendmode to the Excuisit (upscale clothing) and from there you went back to your own store. And everywhere you took stuff (to bargain with) and picked up bags and sometimes you did not know what was in it. In a way, this was really fun.

The acquisition of desirable goods went hand in hand with having established important social ties (Berdahl, 1999). The fact that all consumer goods are now available for money removed one of the motivations to maintain complex social networks. Less social interaction and decreased feelings of uniqueness (of obtaining hard to find goods) affected the enjoyment of consumption.

An additional idea linked to anti-consumption sentiments among East Germans is the perceived lower quality of consumer goods available after reunification. Participants stated that they generally believed that goods from GDR times were sturdy, made to last, and repairable. Most of our informants noticed a decline in quality in many newly available products. The following excerpt outlines such quality issues.

There is this phrase "bought cheap is bought twice." And we have experienced that over and over again since the Wall came down. At first, I used to buy cheap because there were so many options. One thought all options were equally good. They pretty much looked the same. But we bad notbing to compare products to unless we tried it. But now I think I'm cured of all that. (Norbert)

Norbert's statement highlights some of the frustration consumers experienced with "cheap" products. Wolfgang also stated his frustration with products he used. His last experience with a "simple" power drill resulted in dissatisfaction as it broke shortly into the job. East Germans were not familiar with varying quality standards for products, thus expected them to perform equally well across a product category. During our interviews, we noticed that products that performed below expectations were immediately compared to earlier experiences with products made in East Germany.

\section{Continued frugality - resistance to contemporary throwawayism?}

Frugal behavior as a response to perceived wastefulness in the West was a recurring theme in our data. Frugality is defined as the 
limiting of expenditures on consumer goods and services, and is characterized by restraint in acquiring possessions, resourceful use of possessions and the avoidance of waste (DeYoung, 1986). Frugal behavior can be attributed to a personality trait learned early in life (Lastovicka et al., 1999), a desire to have less of a negative impact on the environment (Straughan and Roberts, 1999), and/or a less negative effect on people (Pepper et al., 2009). The following section examines the continued frugality behaviors of East Germans. Norbert explains that goods were never disposed of prior to the end of the life cycle.

Everything was kept, nothing was thrown away. In the villages people had their barns, garages, basements, and sheds to store things. Nothing was thrown away. Actually I try to keep all the things as long as I can and if it breaks then I might buy something new. But if it still does the job it is supposed to do, there is no reason to buy something else.

Notice how Norbert repeats the phrase "nothing was thrown away." This phrase was repeated like a mantra - one that was invaluable to Norbert when growing up. Norbert learned that he was better off keeping possessions for future times. He concludes that if a product still performs as it was intended to, there is no reason to replace it. It was interesting to learn that Norbert had bought a new BMW in 2004. When asked, he shared that he plans to drive the car as long as it lasts. Norbert's past experiences more than 20 years ago shaped his behavior to reenact the frugality he once practiced.

East German frugality is a value that is at odds with hyperconsumption. After a trial period of hyperconsumption, many East Germans eventually rejected it, after finding it in opposition to the deeply ingrained value of frugality (Varman and Belk, 2009). A similar case of rejecting hyperconsumption was stated by Ulla who asserts that she came to the realization of unnecessary purchases by participating in hyperconsumption:
I think I became a more conscious consumer by going through all of this [hyperconsumption] after the Wall. Right after the wall came down; I did not think twice about the amount of 'stuff' I was buying.

During our interview, Ulla stated that she was "almost blinded" by the overwhelming choices of consumer goods. Her "weakness" was mail order catalog shopping where she ordered many items for herself, family, and friends. While she enjoyed this type of shopping, she realized that she ended up with many things she did not need. Mandy, one of the two participants that had moved west in the mid 1990s, also realized that current levels of consumption is wasteful. She states:

Well, now we really live in a throw-awaysociety. Who is keeping things these days? For example, cell phones, video games, clothing if they are old, people just throw them away and buy new. I remember back in the GDR, we got our things from older siblings. It did not matter whether they were fashionable or not. No, it was not always great having to get old stuff or not being able to go with some trends, but at least it was not such a waste.

As a young teenager, Mandy did not particularly like hand-me-downs but after trying out hyperconsumptive practices, it just didn't feel right, and she reverted back to her old frugal ways. Other informants (e.g., Theo, Rainer, and Peter) also confirmed hand-medown practices as unchanged behavior in their family. Rainer further stated that "it is not a money question... throwing away perfectly fine things just does not make sense." This is consistent with Zavestoski's (2001) non-spenders who often try to reach an authentic sense of self by resisting consumption.

The transition from socialism to postsocialism changed the dynamics of society and created a "crisis of values" in many of the Eastern countries (Humphrey, 2002: 43). It is clear in our analysis that it was no longer a 
necessity (items are no longer scarce) for informants to behave frugally but they still continue, in part, to resist over-consumption.

I don't want to ride on the money issue all the time. There are things we could afford but we were raised in a way that things bad to last. Whatever works is still today not thrown away. Throwing things away also creates environmental issues. If you throw something away you would bave to buy something that somebody else has to produce. (Rainer)

To summarize this theme, similar to voluntary simplifiers (Ballantine and Creery, 2010) the preferred usage of hand-me-downs and other second-hand goods signifies the resistance of supporting marketers' efforts of selling products. Frugality, is in fact an action of sharing in which is driven by desires for "feelings of unity and an aggregate sense of self" (Belk, 2010: 729). Their willingness to share stems from the marketplace structure and culture where the informants grew up. Theirs was an expression of community (sharing in) but was also a way to survive (sharing out) (Belk, 2010). The informants in this study clearly expressed their dislike for the introduced consumerism, the lighthearted throwawayism, and the overall lack of sustainability views. East Germans' criticism of Western consumption standards echoes previous research, which criticizes consumerism and materialism as failing to improve human well-being (e.g., Kasser, 2002). There is a strong indication of resistance and resentment to today's consumption standards. East Germans became more conscious about Western models of consumption, and these experiences shaped future preferences for re-introduced Eastern brands.

\section{Western brand resistance}

The replacement of familiar Eastern products with Western products not only offered opportunities, but also created challenges for East Germans. The current theme explicates consumer's reaction to the sudden abundance of consumer goods and their unfamiliarity with new brands. Nearly all Western products required East Germans to gain new experiences with brands often causing frustration and confusion. Experience that is negatively disconfirmed can lead to dissatisfaction and subsequent avoidance of or anti-loyalty to brands (Lee et al., 2009b). The following excerpt by Norbert indicates some of the difficulties of simply choosing one brand over the other.

I walked into the store and I couldn't recognize anything. A simple product such as toilet paper became a real task to buy. Back in the GDR we only had one type. Then you saw that they had two sheets and three sheets and different patterns. Which one of them should I buy? I had no idea, nor did I want to spend all this time in the store to find out which brand of paper to buy. Same with margarine, you tried this and that and we decided to stay with Rama. But it took a long time to remember what we liked and why. (Norbert).

Despite increased product choices, informants commented on differences between new Western brands and their preferred Eastern brands. From their reappearance on store shelves, Eastern brands experienced a trendy growth of popularity among East Germans (Economist, 2003). Detlef prefers East German products whenever possible as he perceives their quality as superior.

Although Western products, especially the packaging, looked fancier, they are not always better. We used to bave durable goods that could be repaired over and over... I like buying Eastern brands. (Detlef)

Birgit also stated that Eastern brand quality was better than its reputation, and her experience with Western brands did not live up to expectations. 
The product quality (in GDR) was not that bad. Maybe that's a reason why many old products from that time period are coming back. I'm thinking of the Florena products or the Laundry soaps like Spee. I cannot say that the Eastern products were junk. Today it is a wasteful society. They [manufacturers] want products to break quickly so that you go and buy more. This was not the case with Eastern products.

The re-emergence of Eastern brands and their subsequent popularity is one of the few paths of resistance that East Germans can follow and maintain. The products are perceived as being of higher quality and they also appeal to feelings of nostalgia, or as Rainer calls it "Ostalgie," a portmanteau of the German words Ost (East) and nostalgie (nostalgia). Discourses of "Ostalgie" are related to the view by some informants that it was better in the GDR. By "better" Rainer and others refer to the GDR experience as being "a lot more comfortable, direct, and transparent." By indulging in East German products and thereby resisting the Western brands, they remember a time when they were socially connected and less divided. The decline of close-knit communities results in more individuation and less formal interactions in society (Giddens, 1991). In a sense, the new supply that the marketplace shift brought to GDR empowered its consumers by allowing them to have a choice to resist Western brands (Shaw et al., 2006) and "buycott" (i.e., organized support of preferred products of Eastern brands) (Friedman, 1999).

\section{Discussion}

Anti-consumption activities range "from specific product selection based on ethical and/or ecological considerations, to overall reduced consumption and/or boycott of specific product categories" (Craig-Lees and Hill, 2002: 188). The goal of the study was to obtain a deeper understanding of the (anti-) consumption practices of consumers who have lived through a major market-based transition from a planned economy to a free market structure. The three identified themes described above illustrate a strong aversion and resistance to a throwaway society and a longing for durable, high-quality products. The informants also long for a stronger communal practice and a social connectedness through a less consumption-oriented society. Although some informants welcomed the capitalist system and viewed it as "not bad," they often noted that it had some negative aspects that came along with it. Others viewed themselves as "cheap consumers" and thought of themselves as "thrifty" as they "don't like to throw things away." Several informants shared their disappointment of the lack of quality in the goods that were offered, that "they broke easily," that products were not "as robust as Eastern products that could be repaired," that the West is a "throwaway society," "too consumption oriented," resulting in "a type of non-sensical oversupply of things." Some even reported that it is not as much fun to shop anymore. We found a longing for more values in today's system, more personal responsibility and less consumption orientation in the marketplace. We also found a deep aversion to throwing things away. Many items are still disposed of using alternative voluntary modes (i.e., reused/recycled, shared, exchanged, or donated/handed down to family or second hand stores/charities) before final disposal or ridding (Albinsson and Perera, 2009). In some cases, respondents would save their items in their storage areas such as attics and basements "just in case" they would need it someday.

By illustrating consumers' retention of goods for future use and at the same time as resisting new purchases, our "Continued frugality" theme adds to the literature stream of voluntary simplifiers. Whereas voluntary simplifiers experience periods of de-cluttering to break off their identity ties to goods prior to starting their anti-consumption efforts (Ballantine and Creery, 2010; Nelson et al., 2007; Zavestoski, 2002b), our informants keep storing their items with the belief that they find use for them in the future. Although our 
informants had lived through a form of nonvoluntary simplicity, that was based on necessity prior to 1989 , they now voluntary choose to return to a familiar lifestyle as a response to the capitalist system.

Capitalism created the haves and have-nots in the former East Germany (along with feelings of jealousy). Although, joining the West was the surest path to the materialist utopia that Communism had promised, consumers had to deal with the realization that attaining material wealth did not necessarily equate with happiness. In fact, they seemed to have gone backwards, as capitalism made no promises of food or employment. Progress did not come through "working together" as the Communist ideals stated. Now, progress was achieved by pursuing self-interests. It had become an "elbow society." Adam Smith's notion reigns supreme - pursuing self-interest is the best way to support society. Somehow this does not feel right to many East Germans. This finding extends Zavestoski's (2002b) research on voluntary simplifiers and their quest for authenticity through alternative consumption practices to a broader consumer segment spanning several socioeconomic levels and illustrates that it is not only high-income consumers who struggle with materialism.

In East Germany, everyone had access to the same things and the same income, and they worked together to find the hard-to-get things. Now "things" are what drive them apart. Everyone tries selfishly to attain more by looking for fulfillment through things. In fact, their very identities are now tied to their possessions, and for the first time, they feel like they have to "keep up with the Joneses." Along with new pressures comes the feeling that something special had been lost - Rainer's "comfort, directness, and transparency" have been replaced by insecurity and estrangement (Veenis, 1999). All that is left is "Ostalgie" and about 3000 resurrected East German products (ironically, the rights to many of these products have been purchased and the production subsequently controlled by western companies). In some cases, our informants' resistance to Western brands is likely rooted in a protest against new political ideologies (Sandikci and Ekici, 2009). We find that East Germans have the feeling that they have been duped, not once or twice, but for the third time. Nazism, Communism, and Capitalism (all materialist philosophies) promised material progress. Finally, through capitalism, they have achieved the material abundance that eluded them for almost a century - only to learn that this did not make them any happier.

Our findings further contributes to anticonsumption research by illustrating that anticonsumption behavior can be rooted in ones culture and socialization in addition to being a reaction to disappointing market experiences or political ideologies (Sandikci and Ekici, 2009). The results support a dialogical perspective of anti-consumption where the interplay of personal, societal, and ideological motivations creates a rich anti-consumption culture in the former East Germany. Furthermore, our results indicate that future examinations of whether or not anti-consumption behavior is proactive (internally driven) or reactive (externally driven) are not likely to be as useful as future studies that investigate the differences between selectively driven versus generally practiced anti-consumption (further refining the future research agenda proposed by Lee et al. (2009a)).

\section{Limitations, implications, and future research}

As with most qualitative research based on a small number of informants, a sample of 20 is not considered representative of the entire population of the former GDR. We did try to find a diverse sample in terms of age and occupation; however we cannot assume that all East Germans share these viewpoints.

Marketers need to recognize the long-lasting impact of cultural shaping. While consumers from the former East give the impression of accepting Western symbols and values, psychologically they are still bound by learned cultural beliefs, attitudes, and values 
(Rojsek, 2001). However, it is not necessarily capitalism that is being rejected, but materialism. As Belk (1983) notes, though humans are attracted to the acquisition of the next big material thing, the quest for consumption sometimes brings disenchantment. Many of the informants in this study consider capitalism an "unfriendly market system" due to the decrease in social connectedness and the increase of an "elbow society" where every man and woman is fighting for him/herself. The fact that consumers resist the Western ideal of consumerism should alarm marketers that attempt to gain market share in societies of change.

In order to stay competitive and consumeroriented, product managers need to recognize and act upon the cultural/consumption divide (Varman and Belk, 2009). With this understanding, we recommend that marketing organizations need to be sensitive to the unique cultural background of East Germans and to understand that cheap, non-durable, low-quality products will not be well-received. East Germans prefer longer-term relationships with their products. Planned obsolescence seems to be a primary culprit of East German dissatisfaction. As a result, products that are marketed in East Germany are more likely to appeal to them if they are durable and if they somehow appeal to their feelings of Ostalgie.

Products that enrich the consumption experiences of East Germans by offering a brand community such as a Harley Davidson riding club or a VW Bug community would also be well-received. Advertising campaigns that use humor and joke that the product will last longer than you even want it to or feature images of handing the product down from generation to generation would also be wellreceived in this culture. Excessive product packaging also goes against East German frugality. While in the West, this packaging is thrown away in a bureaucratic and unthinking manner, East Germans will wonder how they can use the excessive product packaging or feel as if they paid too high a price if the company made such a fancy and useless package. Further studies on how East Germans perceive such advertisements, product packaging, and product claims about quality should be undertaken and many of these results may be transferrable to other transition economies such as the rest of Eastern Europe, Russia, and China.

Finally, we call for marketing academics to focus further on the negative aspects of consumption such as feelings of disenchantment that a materialist philosophy tends to bring and the adverse environmental and social consequences that excessive consumption brings. Ironically, if marketers are better able to understand the negative aspects of consumption, they pave the way for the development of products that are more sustainable and better received by the consumer. This, in turn, will lead to continued material and economic growth - the yardstick upon which (for better or worse) - society chooses to measure itself.

\section{Conclusion}

Our study describes a form of anti-consumption where consumers resist the excessive Western consumer culture also known as hyperconsumption. Even 20 years after the fall of the Berlin Wall, it is clear that many East Germans continue to struggle with the political, economic and cultural transformations. The data suggest that many consumers resist change to a consumption-driven ideology and develop a defensive reaction against its norms (Cherrier et al., 2010). Participants raised the concern that hyperconsumption would create unnecessary waste by disposing of products that could be repaired or that were simply out of date. Recurring in our findings is that East Germans would recall ways of handling defective and obsolete products and consequently, re-enact their behavior to avoid needless consumption. East Germans value longer-term relationships with their things and avoid unnecessary consumption and divestment of goods. It is the value-in-use of the products and the possibility of altering them to fit a function of need that many 
consumers grew up with that makes them hold on to their items.

We uncover a deep aversion among East Germans to the modern, bureaucratic and obligatory practice of throwawayism and hyperconsumption. At a deeper level, we find feelings of resentment and betrayal showing that there was a huge discrepancy between the beautiful visions of material abundance and Western affluence that East Germans expected and its reality upon attainment (Veenis, 1999). These feelings uncover a deeper issue with consumption - one that many East Germans have come to realize and merits further exploration - the fact that on some level, all consumption is a disillusioning experience (Campbell, 1987) and that material possessions and abundance are actually driving East Germans apart, making them feel less socially connected. East Germans, like the rest of us, now define themselves by their possessions.

\section{Biographical notes}

Pia A. Albinsson (Ph.D. New Mexico State University) is Assistant Professor of Marketing at Appalachian State University. She researches advertising effectiveness, community networks, and green consumption practices. She has published her research in the European Journal of Marketing, Journal of Consumer Bebaviour, and Advances of Consumer Research.

Marco Wolf (Ph.D. New Mexico State University) is Assistant Professor of Marketing at University of Southern Mississippi. His research centers on consumer behavior, do-it-yourself consumer practices, and the do-it-yourself retailing industry.

Dennis A. Kopf (Ph.D. New Mexico State University) is Assistant Professor of Marketing at University of Wisconsin, Whitewater. He researches ethics and critical theory, green consumption, salesforce development, and the societal effects of advertising. His work has appeared in the Journal of Business Research, the Journal of Business Etbics, and the Journal of Brand Management.

\section{Acknowledgements}

The authors would like to thank the two reviewers and the guest editor for their helpful comments.

\section{References}

Albinsson PA, Perera BY. 2009. From trash to treasure and beyond: the meaning of voluntary disposition. Journal of Consumer Behaviour 8(6): 340-353.

Ballantine PW, Creery S. 2010. The consumption and disposition behavior of voluntary simplifiers. Journal of Consumer Behaviour 9(1): 45-56.

Belk R. 1983. Worldly possessions: issues and criticisms. Advances in Consumer Research 10(1): 514-519.

Belk R. 2010. Sharing. Journal of Consumer Research 36(5): 715-734.

Berdahl D. 1999. Where the World Ended: Re-Unification and Identity in the German Borderland. University Press: Berkeley, CA.

Campbell C. 1987. The Romantic Ethic and the Spirit of Modern Consumerism. Basil Blackwell Ltd: New York, NY.

Cheetham F. 2009. Out of control? An ethnographic analysis of the disposal of collectable objects through auction. Journal of Consumer Bebaviour 8(6): 316-326.

Cherrier H. 2009a. Disposal and simple living: exploring the circulation of goods and the development of sacred consumption. Journal of Consumer Behaviour 8(6): 327-339.

Cherrier H. 2009b. Anti-consumption discourses and consumer-resistant identities. Journal of Business Research 62(2): 181-190.

Cherrier H, Black I, Lee MSW. 2010. Consumer resistance and/or anti-consumption? An analysis of non-consumption in sustainable practices. International Center for Anti-Consumption Research/NACRE 2010 Conference Proceedings, Lee MSW, Roux D, Cherrier H, Cova B (eds). The University of Auckland Business School: Auckland, New Zealand; 20-23.

Cherrier H, Murray JB. 2007. Reflexive dispossession and the self: constructing a processual theory of identity. Consumption, Markets and Culture 10(1): 1-29.

Close AG, Zinkhan GM. 2009. Market-resistance and Valentine's Day events. Journal of Business Research 62(2): 200-207. 
Coulter RA, Feick LF, Price LL. 2000. Changing faces: cosmetics opinion leaderships among women in the new Hungary. European Journal of Marketing 36(11/12): 1287-1308.

Coulter RA, Price LL, Feick LF. 2003. Rethinking the origins of involvement and brand commitment: insights from postsocialist central Europe. Journal of Consumer Research 30(2): 151-169.

Craig-Lees M, Hill C. 2002. Understanding voluntary simplifiers. Psychology and Marketing 19(2): 187-210.

Denegri-Knott J, Molesworth M. 2009. 'I'll sell this and I'll buy that': eBay and the management of possessions as stock. Journal of Consumer Behaviour 8(6): 305-315.

DeYoung R. 1986. Some psychological aspects of recycling. Environment and Behavior 18(4): 435-449.

Economist. 2003. Ostalgie: east German products. The Economist 368(8341): 57.

Etzioni A. 1998. Voluntary simplicity: characteriz ation, select psychological implications, and societal consequences. Journal of Economic Psychology 19: 619-643.

Feick LF, Coulter RH, Price LL. 1995. Consumers in the transition to a market economy: Hungary, 1989-1992. International Marketing Review 12(5): 18-34.

Freestone OM, McGoldrick PJ. 2008. Motivations of the ethical consumer. Journal of Business Etbics 79: 445-467.

Friedman M. 1999. Consumer Boycotts: Effecting Change Through the Marketplace and the Media. Routledge: London.

Galvagno M. 2010. The intellectual structure of the anti-consumption and consumer resistance field: an author co-citation analysis. International Center for Anti-Consumption Research/NACRE 2010 Conference Proceedings. Lee MSW, Roux D, Cherrier H, Cova B (eds). The University of Auckland Business School: Auckland, New Zealand; 10-15.

Giddens A. 1991. Modernity and Self-identity: Self and Society in the Late Modern Age. Polity Press: Cambridge.

Glaser BG, Strauss AL. 1967. The Discovery of Grounded Theory: Strategies for Qualitative research. Aldine de Gruyter: Hawthorne, NY.

Gurdon MA, Savitt R, Pribova M. 1999. Consumer activism in the Czech Republic: the role of exit and voice in a changing economy. Journal of Socio-Economics 28(1): 3-19.

Hetrick W. 1989. The ideology of consumerism: a critique. In Marketing Theory and Practice, Bagozzi R, Peters J (eds). American Marketing Association: Chicago; 40-43.

Hueneke ME. 2005. The face of the un-consumer: an empirical examination of the practice of voluntary simplicity in the United States. Psychology and Marketing 22(7): 527-550.

Humphrey C. 2002. The Unmaking of Soviet Life: Everyday Economies After Socialism. Cornell University Press: Ithaca, NY.

Iyer R, Muncy JA. 2009. Purpose and object of anticonsumption. Journal of Business Research 62(2): 160-168.

Kasser T. 2002. The High Price of Materialism. The MIT Press: Cambridge, MA.

Kilbourn W, McDonagh P, Prothero A. 1997. Sustainable consumption and the quality of life: a macromarketing challenge to the dominant social paradigm. Journal of Macromarketing 17(1): 4-24.

Kopf D, Boje D, Torres I (in press). The good, the bad and the ugly: dialogical ethics and market information. Journal of Business Etbics.

Kozinets RV, Handelman JM. 2004. Adversaries of consumption: consumer movements, activism, and ideology. Journal of Consumer Research 31(3): 691-704.

Lastovicka JL, Bettencourt LA, Hughner RS, Kuntze RJ. 1999. Lifestyle of the tight and frugal: theory and measurement. Journal of Consumer Research 26(1): 85-98.

Lee MSW, Fernandez KV, Hyman MR. 2009a. Anti-consumption: an overview and research agenda. Journal of Business Research 62(2): 145-147.

Lee MSW, Motion J, Conroy D. 2009b. Anti-consumption and brand avoidance. Journal of Business Research 62(2): 169-180.

Lincoln YS, Guba EG. 1985. Naturalistic Inquiry. Sage: Beverly Hills, CA.

Ludwig A. 1999. Fortschritt, norm und eigensinn. In Fortschritt Norm und Eigensinn: Erkundungen im Altag der DDR, Ludwig A (ed.). Christoph Links Verlag: Berlin.

Madarász JZ. 2006. Working in East Germany: Normality in a Socialist Dictatorship, 19611979. Palgrave Macmillan: NY. 
Meuschel S. 1992. Ligitimation und Parteiberrschaft in der DDR: Zum Paradox von Stabilität und Revolution in der DDR 1945-1989. Suhrkamp: Frankfurt/M.

Moisander J, Pesonen S. 2002. Narratives of sustainable ways of living: constructing the self and the other as a green consumer. Management Decision 40(4): 329-342.

Nelson MR, Rademacher MA, Paek HJ. 2007. Downshifting consumer - upshifting citizen? An examination of a local freecycle community. Annals of the American Academy of Political and Social Science 611(1): 141-156.

Peneloza L, Price LL. 1993. Consumer resistance: a conceptual overview. Advances in Consumer Research 20(1): 123-128.

Pepper M, Jackson T, Uzzell D. 2009. An examination of the values that motivate socially conscious and frugal consumer behaviours. International Journal of Consumer Studies 33: 126-136.

Rojsek I. 2001. A comparison of the purchasing and consumption behavior of Slovenian and other Eastern European consumers. International Marketing Review 18(5): 509-520.

Sandikci Ö, Ekici A. 2009. Political motivated brand rejection. Journal of Business Research 62(2): 208-217.

Santino J. 1996. New Old Fashion Ways: Holidays and Popular Culture. University of Tennessee Press: Knoxville.

Schor J. 1998. The Overspent American: Why We Want What We Don't Need. Basic Books: NY.

Shaw D, Moraes C. 2009. Voluntary simplicity: an exploration of market interactions. International Journal of Consumer Studies 33(2): 215-223.

Shaw D, Newholm T. 2002. Voluntary simplicity and the ethics of consumption. Psychology and Marketing 19(2): 167-185.
Shaw D, Newholm T, Dickinson R. 2006. Consumption as voting: an exploration of consumer empowerment. European Journal of Marketing 40: (9/10): 1049-1067.

Sherry JF. 1990. A sociocultural analysis of a Midwestern flea market. Journal of Consumer Research 17(1): 13-30.

Spehrlich PW. 2006. Oppression and Scarcity: The History and Institutional Structure of the Marxist-Leninist Government of East Germany and some perspectives on Life in a Socialist System. Praeger Publishers: Westport.

Straughan RD, Roberts JA. 1999. Environmental segmentation alternatives: a look at green consumer behavior in the new millennium. Journal of Consumer Marketing 16(6): 558-575.

Thompson CJ, Arsel Z. 2004. The Starbucks brandscape and consumers' (anticorporate) experience of glocalization. Journal of Consumer Research 31(3): 631-642.

Varman R, Belk R. 2009. Nationalism and ideology in an anticonsumption movement. Journal of Consumer Research 36(4): 686-700.

Veenis M. 1999. Consumption in East Germany: the seduction and betrayal of things. Journal of Material Culture 4(1): 79-112.

Zavestoski S. 2001. Environmental concern and anti-consumerism in the self-concept: do they share the same basis? In Exploring Sustainable Consumption: Environmental Policy and the Social Sciences, Murhpy J, Cohen MJ (eds). Pergamon, Press: Amsterdam; 179-189.

Zavestoski S. 2002a. Guest editorial: anticonsumption attitudes. Psychology and Marketing 19(2): 121-126.

Zavestoski S. 2002b. The social-psychological bases of anti-consumption attitudes. Psychology and Marketing 19(2): 149-165. 